The Quarterly Journal of Austrian Economics

Volume 24 | NO.3 | 397-430 | Fall 2021

WWW.QJAE.ORG

\title{
Has the Rise of Socialism in US Politics Been a Boon to Austrian ECONOMICS? EvidENCE FROM SOCIAL Media And Other Metrics
}

\author{
G. P. Manish, Franklin G. Mixon Jr., and Mark Thornton*
}

Jel Classification: A11, B51, B53, P21, P22, P27

AвSTRACT: The rise of socialism has been one of the more dramatic movements in US politics in the modern era, with recent Gallup polling indicating that 39 percent of Americans (and 65 percent of Democrats) hold a favorable view of the political economic ideology. Upward trends in the popularity of political economic ideologies such as socialism are observed when much of what is known by the public about them is gleaned through heuristic approaches rather than through scientific investigation. However, an increase in the persistence and severity of problems resulting from the practice of a political economic ideology such as socialism will likely lead to more science-based introspection, a turn in approach that will almost certainly be a boon to political and economic theories/models offering refutations of the ideology. This study explores such a demand-side argument with regard to the recent rise of socialism in US politics by asserting, and testing, the notion that the Austrian school of economics,

\footnotetext{
* The authors thank three anonymous reviewers for helpful comments on a prior version. Any remaining errors are our own.

G. P. Manish (gmanish@troy.edu) is BB\&T Professor of Economic Freedom at the Manuel H. Johnson Center of Political Economy at Troy University in Troy, Alabama. Franklin G. Mixon Jr. (mixon_franklin@columbusstate.edu) is Thomas Buck Jr. Professor of Economics at the Center for Economic Education at Columbus State University in Columbus, Georgia and a corresponding author. Mark Thornton (mthornton@mises.org) is Peterson-Luddy Chair in Austrian Economics at the Mises Institute in Auburn, Alabama.
} 
which is most closely identified with the claim that socialism is unworkable, has been a beneficiary of recent political trends. Statistical evidence from various trends in informetrics is consistent with our assertion, as Google News hits and Twitter hashtag counts have ascended over the recent period (i.e., 2016 to 2019).

\section{INTRODUCTION}

$\mathrm{T}$ he increase in support for socialism in US politics has been one of the more dramatic movements in the modern political era. Gallup polling near the end of 2019 indicated, for example, that 47 percent of Americans believe that government should do more to solve problems, up from 36 percent in similar polling from 2010 (Jones and Saad 2019). Similarly, a "preference" for "active government" and a "positive view" of "socialism" rose by eight and three percentage points, respectively, over this same time, climbing from 34 percent to 42 percent in the former case and from 36 percent to 39 percent in the latter case (Jones and Saad 2019). Increases in the favorability of socialism among Democrats have been even more pointed, reaching a new high of 60 percent in 2016, which Jones and Saad (2019) suggest "may have reflected the influence of avowed Democratic socialist Bernie Sanders' 2016 presidential campaign." The trend continued in 2019, when 65 percent of Democrats polled reflected favorability toward socialism.

Upward trends in the popularity of political economic ideologies such as socialism are more likely to be observed when much of what is known by the public about them is gleaned through heuristic approaches rather than through scientific investigation. For many in the US, the recent experiences of Venezuela serve as the heuristic lens through which the pitfalls of socialism are understood. Since 2013, economic output has fallen dramatically, and hyperinflation has paralyzed the country's economy, with the typical Venezuelan adult losing as much as twenty-four pounds of body weight in 2017 alone (Sequera 2018). ${ }^{1}$ To outside observers, however, Venezuela's

\footnotetext{
${ }^{1}$ Economic output in Venezuela fell by 16 percent in 2016, and by 14 percent in 2017, while inflation, which stood at 112 percent in 2015, rose to 2,400 percent in 2016 (Flannery, 2018). By August of 2019, Venezuelan inflation stood at 10 million percent, while the cumulative decline in its economy since 2013 reached 65 percent (Sanchez, 2019). At the same time, 4 million Venezuelans, or about 10 percent of the
} 
economic problems may be rationalized as simply the result of the malpractice of socialism by the country's ruling elites (e.g., President Nicolás Maduro), and not the result of inherent problems with socialism as a political economic ideology. To insiders, the opposite conclusion is likely to be drawn.

To either group, any increase in the persistence and severity of the economic problems resulting from the practice of a political economic ideology such as socialism will likely lead to more science-based introspection about that ideology. Such a turn in approach will almost certainly be a boon to political and economic theories and models offering thorough refutations of the ideology. This study explores such a demand-side argument with regard to the recent rise of socialism in US politics. More specifically, it asserts, and tests, the notion that the Austrian school of economics has been a beneficiary of the recent growth in the favorability of socialism in US politics. This assertion is based on the premise that the scholarship of economists belonging to this school, particularly Ludwig von Mises (1881-1973) and Friedrich Hayek (1899-1992), represents what is arguably the most renowned rebuke of claims of socialism's superiority as a method of political and economic organization.

Statistical evidence from various trends in informetrics supports our assertion, as Google News hits and Twitter hashtag counts involving the views of prominent Austrian economists have ascended over the recent period from 2016 to 2019. The more recent era corresponds to the period of increased support for socialism in US politics as expressed through the increasing political fortunes of Bernie Sanders, Alexandria Ocasio-Cortez, and other prominent US legislators. Before turning to the statistical evidence, however, this study first provides a primer on the recent increase in support for socialism in US politics since 2016 and a brief examination of the views of two prominent Austrian economists-Mises and Hayekon the shortcomings of socialism as a political economic ideology.

country's population had fled the country, decimating the country's professional class (Sanchez, 2019). Lastly, the Venezuelan practice of eating two or fewer meals each day is often referred to as "the socialist diet." 


\section{INCREASING SUPPORT FOR SOCIALISM IN US POLITICS, 2016-PRESENT: A PRIMER}

The recent increase in support for socialism in modern US politics has been embodied by the political ascendancy of Bernie Sanders, an independent US senator from Vermont. Sanders, who refers to himself as a "democratic socialist," announced his first presidential run on April 30, 2015. ${ }^{2}$ During interviews just before his public campaign announcement, Sanders indicated that trade, income inequality and healthcare would be key issues in his campaign (Merica 2015). Sanders's 2016 presidential run most prominently included plans to (1) fund a single payer healthcare system by raising income tax rates, referred to as "Medicare for All," (2) increase the tax rate on capital gains and dividends, (3) raise taxes on corporations, and (4) combat climate change by imposing a tax on carbon emissions. ${ }^{3}$ According to some analyses, Sanders's policy proposals would have added $\$ 18$ trillion to the federal budget deficit over ten years, even after the collection of $\$ 15.3$ trillion in new tax revenues (Mermin, Burman, and Sammartino 2015).

\section{The 2016 Democratic Presidential Primary}

The 2016 Democratic Party presidential primary season began in February of 2016, with Sanders's opponent, former US secretary of state Hillary Clinton, winning in Iowa, Nevada, and South Carolina. Still, Sanders won the New Hampshire primary, and on "Super Tuesday" (March 1, 2016), Sanders added victories in Colorado, Minnesota, Oklahoma, and Vermont. Later, on March 4, 2016, Sanders won the primaries in Kansas and Nebraska, and on the following day he won in Maine. March 2016 would also see Sanders claim primary victories in Alaska, Hawai'i, Idaho, Michigan, Utah, and Washington, while in April he would win in Rhode Island, Wisconsin,

\footnotetext{
${ }^{2}$ Born in Brooklyn, New York, Sanders moved to Vermont after graduating from the University of Chicago. His first successful run for office came in 1981, when he was elected Burlington's mayor by only ten votes (Merica 2015). Later, in 1990, he was elected Vermont's at-large member of Congress, and almost twenty years later, in 2007, he was elected to the US Senate (Merica 2015).

${ }^{3}$ See Ballotpedia s.v. “Bernie Sanders Presidential Campaign, 2016," accessed Aug. 9, 2021, https://ballotpedia.org/Bernie_Sanders_presidential_campaign,_2016.
} 
and Wyoming. Sanders continued winning state primaries into May 2016, taking victories in Indiana, Oregon, and West Virginia, while in June he added wins in Montana and North Dakota. Even with these individual successes, Clinton would ultimately claim a majority of the pledged delegates $(2,205-1,846)$ in victory over Sanders. ${ }^{4}$

Despite his defeat in 2016, Sanders's performance against Clinton made it clear that his socialist platform was a force for prospective political foes to reckon with. This realization was only buttressed by the sense among many voters that Clinton's 2016 Democratic presidential primary victory was tainted by the participation of 712 so-called superdelegates in the Democratic National Convention vote. Clinton garnered 602 superdelegates, four hundred of whom had committed to her campaign before the first caucus or primary. ${ }^{5}$ This sense was later supported by revelations in Brazile (2017) that the 2016 Democratic caucuses and primaries were engineered in various ways to produce a Clinton victory.

\section{The Justice Democrats and the 2018 Midterm Elections Cycle}

One backlash against these 2016 events occurred one year later, in 2017, when the progressive political action committee known as Justice Democrats was formed by Kyle Kulinski of Secular Talk, Cenk Uygur of The Young Turks, and former Sanders presidential campaign executives Saikat Chakrabarti and Zack Exley (Grigoryan and Suetzl 2019). ${ }^{6}$ According to Grigoryan and Suetzl (2019), Justice Democrats supports and endorses working-class progressive candidates who seek political office, and its platform includes, but is not limited to, a reorganization of the entire US economy with a focus on preventing climate change (i.e., the "Green New Deal"), a federal jobs guarantee, free universal education (through college) and healthcare (both as human rights), paid maternity and vacation leave, free childcare, and raising the minimum wage. ${ }^{7}$

\footnotetext{
${ }^{4}$ Delegate totals collected from cnn.com.

${ }^{5}$ See cnn.com and pbs.org.

${ }^{6}$ Secular Talk is a progressive political podcast. The Young Turks is an alternative media (online) political news and entertainment company that supports progressivism.

${ }^{7}$ See also https://www.justicedemocrats.com/home.
} 
The Justice Democrats political platform's first foray into federal elections occurred during the 2018 midterm elections cycle, when the organization endorsed seventy-three congressional candidates, twenty-four of whom won party primaries. Seven of these twenty-four ultimately won seats in the US Congress (Grigoryan and Suetzl 2019). That group included Alexandria Ocasio-Cortez (D-NY), Ilhan Omar (D-MN), and Rashida Tlaib (D-MI), and since taking office in January 2019, these three representatives have become some of the most prominent federal legislators of the current era. Key among them is Ocasio-Cortez, whose political fame rose after a thirteen-point victory over an incumbent representative in the 2018 Democratic primary. ${ }^{8}$ Ocasio-Cortez, who won the 2018 general election by about sixty-five points, ran on a socialist political platform supporting Medicare for All, a federal jobs guarantee, housing as a human right, immigration justice, and higher education for all. ${ }^{9}$ Since taking office in January 2019, Ocasio-Cortez's political influence has risen to the point of rivalling that of Nancy Pelosi (D-CA), the speaker of the US House of Representatives (Caygle, Ferris, and Bresnahan 2019; and Lovelace 2019).

\section{The Run-Up to the 2020 Presidential Election}

Following his meteoric rise during the 2016 Democratic presidential primaries, in February 2019 Sanders announced his candidacy in the 2020 US presidential election. In announcing his bid on Vermont Public Radio, Sanders pointed to the Democratic Party's leftward shift since 2016 as a reason for a second run (Detrow and Taylor 2019). As Sanders explained (Detrow and Taylor 2019),

It turns out that many of the ideas that I talked about [in 2016] - that health care is a right, not a privilege, and that we've got to move toward a Medicare-for-all, single-payer system ... [and] raise the minimum wage to $\$ 15$ an hour.... [Then, w] hen I talked about making public colleges and universities tuition-free and lowering student debt, that was another issue that people said was too radical. Well, that's also happening around the country.

\footnotetext{
${ }^{8}$ Chakrabarti became Ocasio-Cortez's first chief-of-staff.

${ }^{9}$ See Ballotpedia s.v. "Alexandria Ocasio-Cortez," accessed Aug. 9, 2021, https:// ballotpedia.org/Alexandria_Ocasio-Cortez.
} 
Sanders's renewed push for the White House got a boost when incumbent representative Ocasio-Cortez offered her endorsement for Sanders's campaign at a rally in Queens, New York, just days after another incumbent, Omar, offered her public support for Sanders's socialist agenda (Gathright and Martin 2019). A few days later Tlaib, another incumbent representative, joined Omar and Ocasio-Cortez in stumping for Sanders's 2020 election bid (Krieg and Grayer 2019). These endorsements helped to propel Sanders's candidacy, built upon a socialist platform, into the lead among a relatively large field of Democrats vying to become the forty-sixth president of the United States.

\section{AUSTRIAN ECONOMISTS ON SOCIALISM}

As Holcombe $(2014,46)$ points out, many economists during the twentieth century considered the Austrian school of economics (hereafter Austrian school) the most closely identified with the claim that central planning is unworkable. Central to that claim is the idea that prices are necessary for rational economic calculation (Holcombe 2014, 46). This idea originated in a presentation by Ludwig von Mises, a titan of the Austrian school, during a 1919 meeting of the Vienna Economic Society. That presentation, which evolved into an academic paper the following year (Mises 1990), launched what became known as the socialist calculation debate. ${ }^{10}$ Two years later Mises's paper was expanded into a book (Mises 1960), and in the decades that followed, another giant of the Austrian school joined in his efforts to explain the pitfalls of socialism, namely Friedrich Hayek. ${ }^{11}$ For his part, Hayek (1948) concentrated on the entrepreneurial and innovative functions that lead to economic progress in a market economy, which is well suited to coordinate the decentralized knowledge that is held by market participants (Holcombe 2014, 51). ${ }^{12}$

Together, these two economists led the Austrian school's critique of socialism as an economic and political ideology. In fact,

\footnotetext{
${ }^{10}$ See Holcombe $(2014,46)$.

${ }^{11}$ See Holcombe $(2014,46)$.

${ }^{12}$ Hayek was awarded the Nobel Prize in Economic Sciences in 1974 for his work on the theory of money and economic fluctuations, and for his analysis of the interdependence of economic, social, and institutional phenomena.
} 
Holcombe $(2014,51)$ argues that it was the ideas about rational calculation developed by the Austrian school in the socialist calculation debate that helped develop the unique identity of the school. Many of the more recent contributions from Austrian school economists, such as George Reisman of Pepperdine University and Sanford Ikeda of the State University of New York (Purchase College), have extended the understanding of the implications of the information problems involved in attempting to plan out the economic order (Holcombe 2014, 51). ${ }^{13}$ This research, in turn, has been supplemented by the work of Peter Boettke and Christopher Coyne, both of George Mason University. ${ }^{14}$ In the section that follows, a more detailed review of Mises's and Hayek's contributions vis-à-vis the pitfalls of socialism is presented.

\section{MISES AND HAYEK ON SOCIALISM}

Mises is the foremost opponent of socialism in history. He was an economist from Austria who dealt with the practical affairs of the time using the deductive theory approach of the Austrian school of economics based in Vienna. In the economic chaos following World War I, European governments began implementing socialism, with Austria's leadership seeking to adopt Russian-style bolshevism. Mises convinced the Austrian political leader, Otto Bauer, to eschew socialism altogether, saving the country from its deleterious effects (Hülsmann 2007, 331-35).

Mises then set out to prove that socialism was untenable, indeed impossible. In doing so he wanted to go beyond the standard criticisms of socialism, such as the past failures of applied socialism and the problem of incentives under socialism. In developing his argument Mises made two important assumptions. First, he assumed that a socialist economy is a closed economy where the ownership of the available means of production is centralized: the state decides what to produce, how to produce it, and how it will be distributed. Second, he assumed that the planner(s) would be altruistic, brilliant, and have access to all available technical knowledge.

\footnotetext{
${ }^{13}$ See Ikeda (1997); and Reisman (1998).

${ }^{14}$ See Boettke (1990, 1994, and 2000); and Boettke and Coyne (2004).
} 
His calculation argument focused on capital goods, their production and allocation (Mises 1990). Capital goods (e.g., tools and machines) must be replaced as they wear out. In a static economy (i.e., one that is in a state of long-run equilibrium) this could be achieved simply by replacing worn parts or the capital goods themselves. In such a scenario all the means of production, including the available capital goods, have already been allocated to satisfy their most highly valued uses. Thus, there is no possibility of reallocating the available resources and improving the well-being of consumers. The same goods will be produced in the same quantities period after period, and there will be no need to alter the existing bundle of capital goods.

However, in a real economy most things are subject to change, and simple replacement of existing capital goods is not feasible. The real world is characterized by constant changes in technology, population, migration patterns, demographics, and the weather, and some resources will inevitably become more valuable, and others less, while some resources will inevitably become more abundant and others scarcer. This incessant change means that the available producer goods, at any given moment, are not allocated to satisfy their highest-valued uses; there is room to reshuffle and change the allocation of resources and improve overall well-being. Making these changes requires economic calculation: it requires a comparison of the marginal benefit and the opportunity costs involved in any production decision.

In the simple world of a Crusoe economy, producer goods can be allocated without reducing costs and benefits to a common denominator. If the structure of capital is relatively sparse and production processes are not very complex or lengthy, an actor can easily isolate the amount of consumer goods that are dependent on the use of a producer good in different production processes. As a result, the costs and benefits involved can be reduced to satisfaction obtained versus satisfaction foregone, and a decision can be made by weighing the two satisfactions, one against the other.

In a well-developed economy, however, the problem of resource allocation is far more complex. Producing consumer goods now involves several steps or stages, with all but the final step resulting in the production of capital goods to assist in further production. Many 
of these capital goods are highly nonspecific, creating an immense number of relationships of substitutability and complementarity throughout the production structure. In such a scenario, the allocation of producer goods requires the costs and benefits of a decision to be reduced to a common denominator: it requires the use of cardinal numbers in the mental process that precedes the decision to allocate a certain resource toward one particular end and not the other.

Given the inherently ordinal nature of economic value and utility, this will be impossible for the socialist planner to accomplish. In socialist societies there is one entity that owns the means of production (i.e., the state or central planner), and no exchange of producer goods takes place, which, therefore, means that no prices for these goods exist. Shorn of such prices, the planner finds it impossible to compare the anticipated marginal benefit and opportunity cost of any production decision. As a result, socialism is inherently irrational. ${ }^{15}$

In a market society, entrepreneurs calculate how to proceed with production based on the money prices of the factors of production and their estimate of the future prices of their products. These prices are established in the process of exchange, which presupposes two or more trader-owners. Markets and money are therefore the essential prerequisites for solving the problem of economic calculation and for making meaningful decisions regarding the allocation of the available factors of production.

When market prices serve as a common denominator for comparing the costs and benefits associated with a particular production project, production decisions can be made without a survey of all the steps that lie between the given decision and the ultimate production of consumer goods. A market economy is characterized by an "intellectual division of labor," where no entrepreneur is forced to isolate the potential satisfaction gained and lost as a result of his (or her) decisions (Mises 1990, 15). Instead, he can

\footnotetext{
${ }^{15}$ In order to gain a proper understanding of Mises's argument, it is worth noting that Rothbard, Mises's foremost American student, extended Mises's calculation argument by showing that the same problems associated with the socialist state would also exist in a world where one corporation owned all the means of production (Rothbard [1962, 1970] 2009, 609-16). That is, a rational economy requires multiple property owners.
} 
focus solely on estimating the prices that he expects to receive for the particular products that he is engaged in producing, while the connection between entrepreneurial decisions and consumer preferences results from the numerous decentralized decisions made by entrepreneurs in the various stages of production.

Mises would go on to write a six hundred-page treatise on socialism in 1922, titled Socialism: An Economic and Sociological Analysis, in which he delves into greater detail about the socialist calculation problem and other negative effects of socialism, as well as the superiority of capitalism (Mises 1962). This book and his earlier article ignited the socialist calculation debate between pro- and antisocialist economists, as well as among pro-socialism economists such as Henry Douglas Dickinson (1899-1969), Maurice Dobb (1900-76), Oskar R. Lange (1904-65), Abba P. Lerner (1903-92), and Fred M. Taylor (1855-1932) in terms of how to best solve the problem. ${ }^{16}$

Another prominent participant in the socialist calculation debate was Hayek, a Viennese student of Mises's. Over the course of this debate Hayek defended and elaborated on Mises's argument regarding the impossibility of economic calculation under socialism (Hayek 1948, 57-91). Hayek focused on the difference between scientific or technical knowledge, which is objective, and the subjective knowledge that guides resource allocation in a dynamic world. The planners, he argued, could easily collect the former type of knowledge. But such knowledge will not help them make meaningful production decisions. What the planners will lack is the subjective knowledge of the "man on the spot," who is the driving force of the market economy (Hayek 1948, 83). This knowledge, which is necessarily time and place specific, is impossible for the planners to obtain, given that much of it is tacit and only revealed as the process of pricing and exchange unfolds in a market economy. ${ }^{17}$

\footnotetext{
${ }^{16}$ See Hayek (1935); Hoff (1949); Lavoie ([1985] 2015); Ekelund and Hébert (2014); and Holcombe (2014) for an overview of the socialist calculation debate. For work by the prosocialist economists, see Lange and Taylor (1938); Dobb (1937); Dickinson (1939); and Lerner (1946).

${ }^{17}$ The following passage from Hayek $(1948,80)$ illustrates the kind of time- and place-specific knowledge that is crucial for resource allocation: "To know of and put to use a machine not fully employed, or somebody's skill which could be better utilized, or to be aware of a surplus stock which can be drawn upon during an interruption of supplies, is socially quite as useful as the knowledge of better
} 
There have since been a number of criticisms and suggested remedies for the calculation problem by socialist economists. There have even been a number of reinterpretations of the problem offered by Austrian economists. However, Mises's argument remains valid, as Salerno $(1990,66)$ concludes:

Thus Mises's original thesis stands on its own against all counterarguments and without any need for qualification or emendation: without private ownership of the means of production, and catallactic competition for them, there cannot exist economic calculation and rational allocation of resources under conditions of the social division of labor. In short, socialist economy and society are impossible.

Some people felt that Mises's argument was correct when Russia quickly collapsed after adopting socialism and was forced to readopt money, prices, wages, and other features of capitalism with the New Economic Policy. Others accepted that Mises was correct when his theory remained unblemished by his critics during the socialist calculation debate. Finally, when the propped-up pseudo-communist economies in the Soviet Union, Eastern Europe, and China collapsed, most observers concurred with Mises. ${ }^{18} \mathrm{~A}$ very successful pro-socialism economist, Robert Heilbroner (1989), confessed that "[i]t turns out, of course, that Mises was right." Heilbroner (1992) later wrote,

Capitalism has been as unmistakable a success as socialism has been a failure. Here is the part that's hard to swallow. It has been the Friedmans, Hayeks, and von Miseses who have maintained that capitalism would flourish and that socialism would develop incurable ailments. All three have regarded capitalism as the "natural" system of free men; all

alternative techniques. The shipper who earns his living from using otherwise empty or half filled journeys of tramp-steamers, or the estate agent whose whole knowledge is almost exclusively one of temporary opportunities, or the arbitrageur who gains from local differences of commodity prices are all performing eminently useful functions based on special knowledge of circumstances of the fleeting moment not known to others."

${ }^{18}$ There is now an extensive literature that focuses on the economic failure of central planning from an Austrian perspective, especially in the cases of the Soviet Union and India. For the Soviet Union, see Boettke (1990 and 2000) and Boettke and Coyne (2004). For India, see Shenoy (1958, 1963, and 1966; Shenoy (1971); and Manish (2011, 2013, and 2014). Also see the essays in Boettke (1994). 
have maintained that left to its own devices capitalism would achieve material growth more successfully than any other system.

Others had heard of Mises and his theory of socialism too. When the Nazis (i.e., national socialists) invaded Austria in 1938 they sent a special unit to Mises's apartment. Mises had already moved to Switzerland for his safety. However, the Germans took all of Mises's papers and even his furniture. Modern American Austrian economists believed that the papers had been destroyed in the war, but after the collapse of communism beginning in 1989 the papers were found in a Committee for State Security (KGB) warehouse near Moscow. Apparently, both types of socialists-fascists and communists-felt that Mises was right about socialism but that he was withholding the solution to the problem of socialist calculation for ideological reasons.

New interest in socialist ideas is disturbing because of the potential severe damage they could inflict on the economy. The only good thing that can be said about the renewed interest in socialism is that it has spurred new interest in Mises and the Austrian school of economics.

\section{GROWING PUBLIC SUPPORT FOR SOCIALISM IN US POLITICS AS A BOON TO AUSTRIAN ECONOMICS}

This section examines various informetrics trends, such as Google News hits and Twitter hashtags usage, that relate to prominent Austrian school economists, namely Mises and Hayek, who opposed socialism as a political and economic ideology. In each case, the ten-year trends are separated into two periods, the period during which the public's favorability toward socialism in US politics increased (2016-19) and the period preceding the rise in socialism's popularity (2010-15). Our statistical analyses of these trends span the two subsections below.

\section{Google News}

Google News is a computer-generated news site that aggregates headlines from news sources worldwide and groups similar stories together. Figure 1 presents a scatterplot of the number of 
Google News hits found in a search process using derivations of the phrase "Austrian school of economics" in combination with the term "socialism."19 The hollow plots (i.e., o) apply to the number of Google News hits found for the 2010-15 portion of the time period under study, all years prior to 2016, when the Democratic Party primaries and caucuses were held. The solid plots (i.e., •) apply to the number of Google News hits found for the 2016-19 period, which includes the 2016 Democratic Party primaries / caucuses and presidential election, the run-up to the 2018 midterm elections; the 2018 midterm elections; the run-up to the 2020 Democratic Party primaries, caucuses, and presidential election; and the 2020 Democratic Party primaries, caucuses, and presidential election. This period, and the events that occurred during it, are associated with the increase in support for socialism in US politics.

\section{Figure 1. Google News hits, 2010-19: Austrian economics}

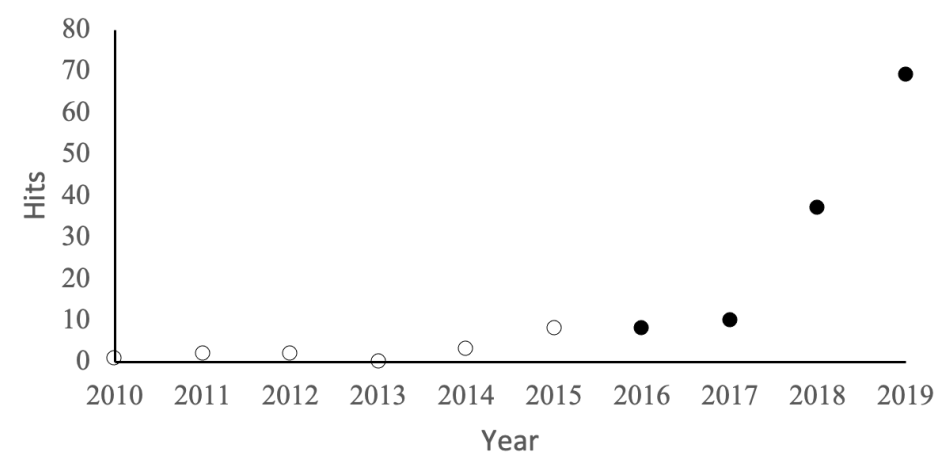

As evident in figure 1, the number of annual Google News hits for the recent period (2016-19) increased over time and the figures generally exceeded those for the earlier period (2010-15). ${ }^{20}$ In fact,

\footnotetext{
${ }^{19}$ These hits or counts were collected manually. The dates of each hit determined in which year the hit was credited. Included among the news and politics sources associated with the Google News hits discovered through our search are The Atlantic, Barron's, Bloomberg, The Economist, Financial Times, Forbes, Los Angeles Times, National Public Radio, The New York Times, New York Post, Politico, The Wall Street Journal, Washington Times, and Yahoo! News, among many others.

${ }^{20}$ A pre-2016 linear trend line indicates that Google News hits increased by only one hit each year for that period. This is compared to a post-2015 linear trend line,
} 
as indicated in table 1, the mean number of annual Google News hits for the more recent period is equal to 31 , compared to a mean of only 2.7 for the earlier period. These figures produce a difference of 28.3, which is consistent with the notion that the recent increase in public support for socialism in US politics has generated greater news (media) interest in the arguments against socialism made by economists in the Austrian school. When subjected to a difference-in-means test, this difference (28.3) is greater than zero at the 0.019 level of significance. ${ }^{21}$

Table 1 also presents information on effect size (Ellis 2010), which indicates how much one group mean differs from another. One particular measure of effect size, Hedges's g, is required in cases where the groups are represented by different sample sizes, as it relies on pooled weighted standard deviations (Hedges 1981; and Hedges and Holkin 1985). ${ }^{22}$ Interpretation of Hedges's $g$ is straightforward. For example, a Hedges's $g$ of 0.75 indicates that the group means differ by three-fourths of one standard deviation. Cohen (1977) suggests a rule of thumb for interpreting effect size wherein a Hedges's $g$ of 0.2 represents a small effect (i.e., not discernable to the naked eye), one of 0.5 represents a medium effect, and one of 0.8 represents a large effect (i.e., discernable to the naked eye). Lastly, given that Hedges's g has been shown to be biased upward in the case of smaller samples, a bias correction is typically recommended. This study employs two bias corrections-the bias correction recommended by Durlak

which indicates that Google News hits increased by twenty-one hits each year for this more recent period.

${ }^{21}$ The null hypothesis for this test is $H_{0}:\left(m_{1}-m_{2}\right) \leq 0$, where $m_{1}$ is the mean number of Google News hits over the 2016-19 period and $m_{2}$ is the mean number of Google News hits over the 2010-15 period. The alternative hypothesis for this test is, $H_{1}$ : $\left(m_{1}-m_{2}\right)>0$.

${ }^{22}$ In our case, Hedges's $g$ is equal to $\frac{m_{1}-m_{2}}{S D_{p}^{*}}$, where $S D_{p}^{*}$ (i.e., the pooled weighted standard deviation) is equal to $\sqrt{\frac{\left(n_{1}-1\right) s_{1}^{2}+\left(n_{2}-1\right) s_{2}^{2}}{\left(n_{1}-1\right)+\left(n_{2}-1\right)}} ; n_{1}$ and $s_{1}$ represent the sample size and standard deviation for Google News hits during the 2016-19 period; and $n_{2}$ and $s_{2}$ represent sample size and standard deviation for Google News hits during the 2016-19 period (Hedges 1981; and Hedges and Holkin 1985). 
(2009) and another recommended by the National Institute of Standards and Technology (NIST). ${ }^{23}$

Table 1. Difference-in-means tests and effect size: Google News hits

\begin{tabular}{|c|c|c|c|c|c|c|c|}
\hline & \multicolumn{5}{|c|}{ Difference-in-means tests } & \multicolumn{2}{|l|}{ Effect size } \\
\hline $\begin{array}{l}\text { Metric } \\
\text { category }\end{array}$ & $\begin{array}{l}2016- \\
2019 \\
\text { Mean }\end{array}$ & $\begin{array}{l}2010- \\
2015 \\
\text { Mean } \\
\end{array}$ & $\begin{array}{l}\text { Difference- } \\
\text { in- } \\
\text { means }\end{array}$ & $\begin{array}{l}t- \\
\text { ratio }\end{array}$ & $\begin{array}{l}p \text { - } \\
\text { value }\end{array}$ & $\begin{array}{l}\text { Hedges's } \\
g\end{array}$ & $\begin{array}{l}\text { Bias- } \\
\text { corrected } \\
\text { Hedges's } g\end{array}$ \\
\hline $\begin{array}{l}\text { Austrian } \\
\text { economics }\end{array}$ & 31.0 & 2.7 & 28.3 & 2.49 & 0.019 & 1.60 & $\begin{array}{l}1.29 \leq g_{\mathrm{bc}} \leq \\
1.44\end{array}$ \\
\hline $\begin{array}{l}\text { Ludwig von } \\
\text { Mises }\end{array}$ & 15.0 & 8.0 & 7.0 & 1.99 & 0.041 & 1.29 & $\begin{array}{l}1.04 \leq g_{\mathrm{bc}} \leq \\
1.16\end{array}$ \\
\hline $\begin{array}{l}\text { Friedrich } \\
\text { Hayek }\end{array}$ & 9.0 & 3.0 & 6.0 & 3.39 & 0.005 & 2.21 & $\begin{array}{l}1.79 \leq g_{\mathrm{bc}} \leq \\
2.00\end{array}$ \\
\hline
\end{tabular}

Note: The smaller bias-corrected Hedges's $g$ above employs the bias correction term recommended by Durlak (2009), while the larger one employs the bias correction term recommended by NIST.

As indicated in table 1, the bias-corrected Hedges's $g$, referred to as Hedges's $g_{\mathrm{bc}}$ for Google News hits referencing both "socialism" and some iteration of the phrase "Austrian school of economics" lies along a range from 1.29 to 1.44 , depending upon which bias correction technique is employed. This result indicates that the mean value of Google News hits during the more recent period (2016-19) is 1.29 to 1.44 standard deviations larger than that of the earlier period (2010-15). This effect size, which is clearly visible in figure 1, is considered large (Cohen 1977).

${ }^{23}$ Both bias corrections involve multiplication of Hedges's $g$ by a bias correction term. That suggested by Durlak (2009) is equal to $\left(\frac{N-3}{N-2.25}\right) \sqrt{\frac{N-2}{N}}$, where $N$ is equal to $n_{1}+n_{2}$. That recommended by NIST is equal to $1-\frac{3}{4 N-9}$. Simulations indicate that the latter of these is more accurate. 


\section{Figure 2. Google News hits: Ludwig von Mises}

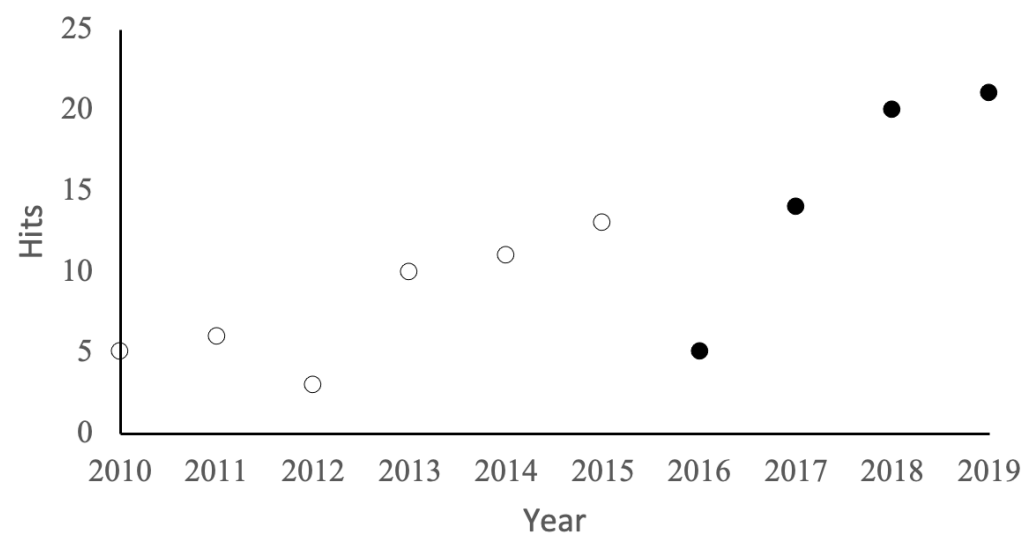

Next, figure 2 presents a scatterplot of the number of Google News hits found from a search process using the name "Ludwig von Mises" in combination with the term socialism. As evident there, the number of annual Google News hits using these terms for the recent period (2016-19) icreased over time and are generally larger than those found for the prior period (2010-15). ${ }^{24}$ Table 1 provides a more formal comparison of these two series. As indicated in the table, the mean number of Google News hits for the more recent period is equal to 15 , compared to a mean of 8 for the earlier period. These figures produce a difference of 7 , which is consistent with the idea that the recent elevation in public support for socialism in US politics has generated greater news (media) interest in the arguments against socialism made by Ludwig von Mises. According to a difference-in-means test, this difference is greater than zero at the 0.041 level of significance. In this second experiment involving Google News, the appropriate effect measure (Hedges's $g_{\mathrm{bc}}$ ) ranges from 1.04 to 1.16 (see table 1), indicating that the mean value of Google News hits during the more recent period (2016-19) is 1.04 to 1.16 standard deviations larger than that of the earlier period

\footnotetext{
${ }^{24}$ A linear trend line the for pre-2016 period indicates that Google News hits increased by only 1.8 hits each year for that period. This is compared to a post-2015 linear trend line, which indicates that Google News hits increased by 5.4 hits each year for this more recent period.
} 
(2010-15). Following Cohen's (1977) rule of thumb, points along this range qualify as a large effect.

Lastly, figure 3 presents a scatterplot of the number of Google News hits found through a search process using the name "Friedrich Hayek" in combination with the term socialism. As it shows, the number of annual Google News hits for the recent period (2016-19) trended upward over time and generally exceeded those for the earlier period (2010-15). ${ }^{25}$ The more formal analysis of these two series presented in Table 1 indicates that the mean number of Google News hits for the more recent period is equal to nine, compared to a mean of only three for the earlier period. These figures produce a difference of six, which is consistent with the notion that the recent increase in support for socialism in US politics has led to much greater news (media) interest in the arguments against socialism made by Friedrich Hayek. According to a difference-in-means test, this difference is also greater than zero at the 0.005 level of significance.

\section{Figure 3. Google News hits: Friedrich Hayek}

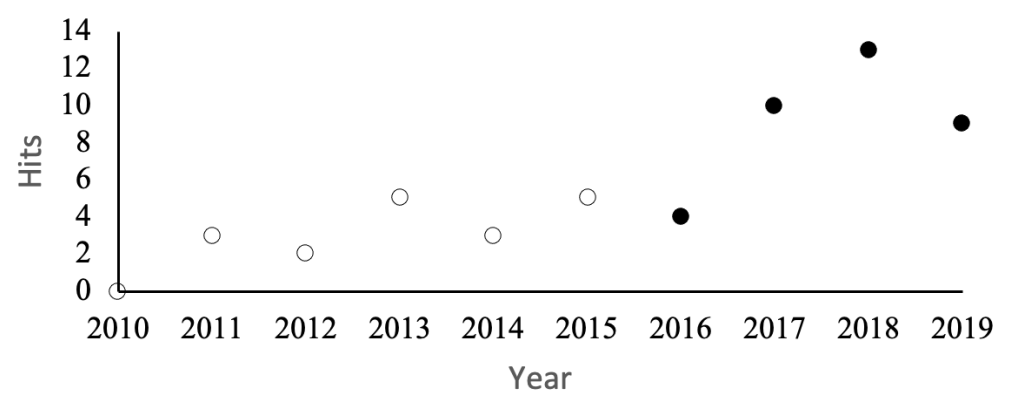

In this final experiment involving Google News, the appropriate effect size measure (Hedges's $g_{\mathrm{bc}}$ ) ranges from 1.79 to 2.00 (see table 1 ), indicating that the mean value of Google News hits during the more recent period (2016-19) is a remarkable 1.79 to 2.00 standard

\footnotetext{
${ }^{25}$ A linear trend line for the pre-2016 period indicates that Google News hits increased by 0.8 each year for that period. This is compared to a linear trend line for the post-2015 period showing that Google News hits increased by 1.8 hits each year for this more recent period.
} 
deviations larger than that of the earlier period (2010-15). This effect size, which is clearly visible upon visual inspection of the plots in figure 3, qualifies as a large effect according to the rule of thumb discussed in Cohen (1977).

\section{Twitter}

Twitter is a social media platform that operates for its users as a microblogging website. Individual posts made by users are referred to as "tweets," each of which is limited to either 140 or 280 characters, depending on the language used by the Twitter user. An individual Twitter user may insert a hashtag symbol (\#) before a relevant keyword or phrase in his or her tweet in order to categorize that tweet and help it show up more easily in a Twitter search. ${ }^{26}$ Clicking or tapping on a hash-tagged word or phrase in any post shows other tweets that include that particular hashtag.

\section{Figure 4. Twitter hashtag frequency: Austrian economics}

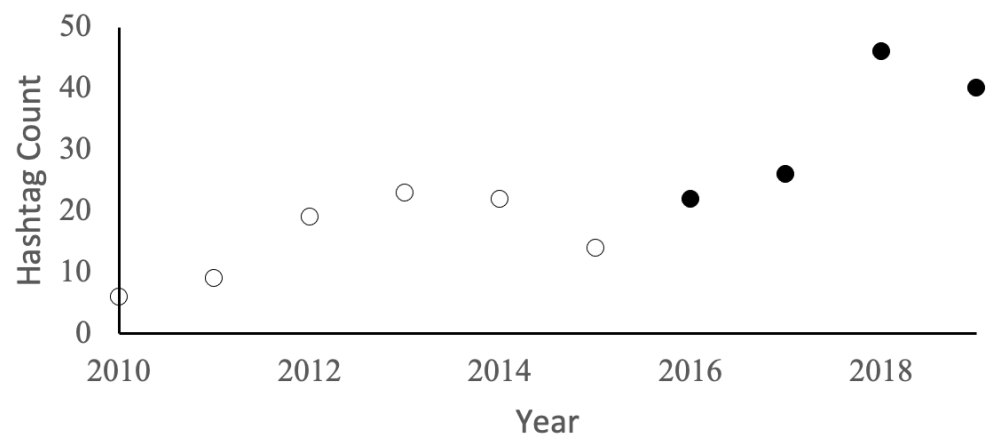

Figure 4 presents a scatterplot of annual Twitter hashtag counts found through a search process using iterations of the Twitter hashtag phrase "Austrian school of economics." As evident in figure 4, the annual Twitter hashtag counts for the recent period (2016-19) trended upward over time and generally exceeded those

${ }^{26}$ See Twitter.com. Twitter hashtags can be included anywhere in a tweet. 
for the prior period (2010-15). ${ }^{27}$ In fact, as indicated in table 2, the mean number of Twitter hashtag counts for the more recent period is equal to 33.5, compared to a mean of only 15.5 for the earlier period. These figures produce a difference of 18 , which is consistent with the proposition that the recent increase in support for socialism in US politics has generated a much greater presence on social media of the arguments against socialism made by Austrian economists. This difference is, according to a difference-in-means test, greater than zero at the 0.007 level of significance.

\section{Table 2. Difference-in-means tests and effect size: Twitter hashtag frequency}

\begin{tabular}{|l|l|l|l|l|l|l|l|}
\hline & \multicolumn{3}{l|}{ Difference-in-means tests } & \multicolumn{3}{l|}{} \\
\hline $\begin{array}{l}\text { Metric } \\
\text { category }\end{array}$ & $\begin{array}{l}2016- \\
19\end{array}$ & $\begin{array}{l}2010- \\
\text { mean }\end{array}$ & $\begin{array}{l}\text { Difference- } \\
\text { in- } \\
\text { mean }\end{array}$ & $\begin{array}{l}\text { means } \\
\text { ratio }\end{array}$ & $\begin{array}{l}\text { p- } \\
\text { value }\end{array}$ & $\begin{array}{l}\text { Hedges's } \\
g\end{array}$ & $\begin{array}{l}\text { Bias- } \\
\text { corrected } \\
\text { Hedges's g }\end{array}$ \\
\hline $\begin{array}{l}\text { Austrian } \\
\text { economics }\end{array}$ & 33.5 & 15.5 & 18.0 & 3.14 & 0.007 & 2.02 & $\begin{array}{l}1.63 \leq g_{\mathrm{bc}} \leq \\
1.82\end{array}$ \\
\hline $\begin{array}{l}\text { Ludwig von } \\
\text { Mises }\end{array}$ & 46.3 & 15.5 & 30.8 & 1.75 & 0.059 & 1.13 & $\begin{array}{l}0.91 \leq g_{\mathrm{bc}} \leq \\
1.02\end{array}$ \\
\hline $\begin{array}{l}\text { Friedrich } \\
\text { Hayek }\end{array}$ & 26.0 & 23.0 & 3.0 & 0.37 & 0.360 & 0.24 & $\begin{array}{l}0.19 \leq g_{\mathrm{bc}} \leq \\
0.22\end{array}$ \\
\hline
\end{tabular}

Note: The smaller bias-corrected Hedges's $g$ above employs the bias correction term recommended by Durlak (2009), while the larger one employs the bias correction term recommended by NIST.

As also indicated in table 2, the Hedges's $g_{\mathrm{bc}}$ for counts of Twitter hashtags referencing some iteration of the term "Austrian school of economics" lies along a range from 1.63 to 1.82, indicating that the mean value of Twitter hashtag counts during the more recent period (2016-19) is 1.63 to 1.82 standard deviations larger than that of the earlier period (2010-15). This compelling effect size can be characterized as large (Cohen 1977).

Next, figure 5 presents a scatterplot of annual Twitter hashtag counts found in a search process using some iteration of the name

\footnotetext{
${ }^{27}$ The pre-2016 linear trend line indicates that Twitter hashtag use increased by only 2.4 hashtags each year for that period. This is compared to the post-2015 linear trend line, which indicates that Twitter hashtag use increased by 7.4 hashtags each year for this more recent period.
} 
"Ludwig von Mises." As indicated there, the annual counts of Twitter hashtags using this name for the recent period (2016-19) are increasing over time and generally exceed those for the prior period (2010-15). ${ }^{28}$ As before, a more formal comparison of these two series is found in table 2. As indicated in the table, the mean of the Twitter hashtag counts for the more recent period is equal to 46.3 , compared to a mean of only 15.5 for the earlier period. These means produce a difference of 30.8 , which is consistent with the hypothesis that the recent increase in support for socialism in US politics has generated a larger presence on social media of the arguments against socialism made by Ludwig von Mises. Moreover, at the 0.059 level of significance, this difference is, according to a difference-in-means test, greater than zero.

\section{Figure 5. Twitter hashtag frequency: Ludwig von Mises}

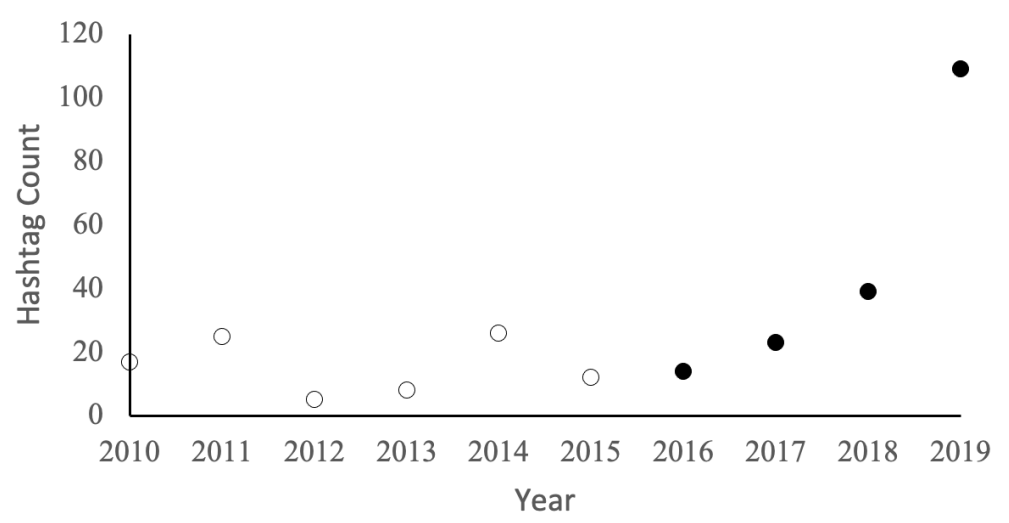

Turning again to table 2, the Hedges's $g_{\mathrm{bc}}$ for counts of Twitter hashtags referencing some iteration of the name "Ludwig von Mises" lies along a range from 0.91 to 1.02 , indicating that the mean value of Twitter hashtag counts during the more recent period (2016-19) is about one standard deviation larger than that of the

\footnotetext{
${ }^{28}$ The pre-2016 linear trend line indicates that Twitter hashtag use fell by 0.5 hashtags each year for that period. This is compared to the post-2015 linear trend line, which indicates that Twitter hashtag use increased by 30.1 hashtags each year for this more recent period.
} 
earlier period (2010-15). Thus, Hedges's $g_{\mathrm{bc}}$ points toward a large effect in this case (Cohen 1977).

\section{Figure 6. Twitter hashtag frequency: Friedrich Hayek}

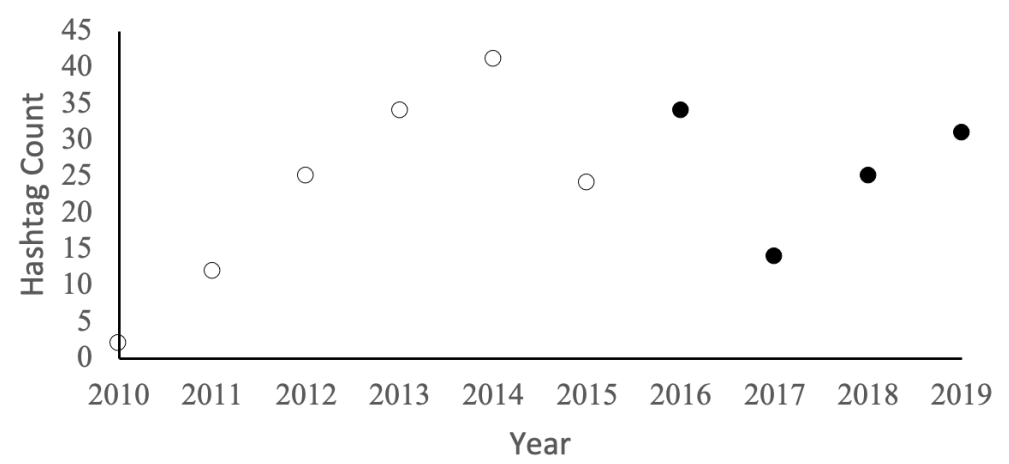

Lastly, figure 6 presents a scatterplot of annual Twitter hashtag counts found using a search process employing iterations of the name "Friedrich Hayek." In this case, although the series trended upward during each separate period, there is no visible difference between annual Twitter hashtag counts for 2016-19 and those for 2010-15. ${ }^{29}$ However, the more formal analysis of these two series found in table 2 indicates that the mean Twitter hashtag count for the more recent period is equal to 26, compared to a mean of 23 for the earlier period. These means produce a difference of 3 , which is consistent with the notion that that the recent rise of socialism in US politics has generated a larger presence on social media of the arguments against socialism made by Friedrich Hayek. However, according to a difference-in-means test this difference is not greater than zero at the usual levels of significance. In this final experiment involving Twitter hashtag counts, Hedges's $g_{\text {bc }}$ ranges from 0.19 to 0.22 (see table 2), indicating that the mean value of Twitter hashtag counts during the more recent period is about one-fifth of one standard deviation larger than that of the

\footnotetext{
${ }^{29}$ The pre-2016 linear trend line indicates that Twitter hashtag use increased by 5.9 hashtags each year for that period. This is compared to the post-2015 linear trend line, which indicates that Twitter hashtag use increased by only 0.2 hashtags each year for this more recent period.
} 
earlier period. Thus, the effect size in this case is small according to Cohen's (1977) rule of thumb.

\section{IS THERE A SUPPLY-SIDE EXPLANATION?}

A potential shortcoming of the analyses above is that they focus solely on the demand-side argument-that the recent increase in the demand for Austrian economics is the result of the rise of socialism in US politics. There is, however, a possible supply-side explanation, with scholars simply producing more academic research in the post-2015 era focusing upon Austrian economics that subsequently attracts the attention of the general public, concerning the observed use of social media in this case. This possibility can to some extent be parsed by examination of Google Scholar trends of citations to Ludwig von Mises and Friedrich von Hayek. Google Scholar is useful for tracking citations of individual scholars (e.g., Mises, Hayek) in academic journals and books. Any structural break between 2015 and 2016, with generally larger and increasing values reported in the post-2015 era, in the two data series provided by Google Scholar for von Mises and Hayek would support a supply-side argument for the social media trends generally observed in the previous section of this study. On the other hand, the absence of a structural break would tend to support our demand-side hypothesis.

\section{Google Scholar}

Google Scholar provides a simple way to find relevant work across the world of scholarly research. ${ }^{30}$ It allows one to explore citations of scholarly work by author and by year, two numerical measures that provide information on the impact of a researcher's scholarship. ${ }^{31}$ Figure 7 presents a scatterplot of Google Scholar citation counts found for Ludwig von Mises. ${ }^{32}$ In this case, although the mean of citations

\footnotetext{
${ }^{30}$ Google.com.

${ }^{31}$ Google.com.

32 The Google Profile function of Harzing (2016) was used for the Google Scholar searches discussed in this study.
} 
for the post-2015 period is slightly larger than for pre-2016, the series lacks an upward trend during the more recent period. In fact, the latter portion of the series trends downward. ${ }^{33}$ Hence, there is no clear evidence in figure 7 to support a supply-side argument for what is generally occurring in the figures presented in the previous section.

\section{Figure 7. Google Scholar citations: Ludwig von Mises}

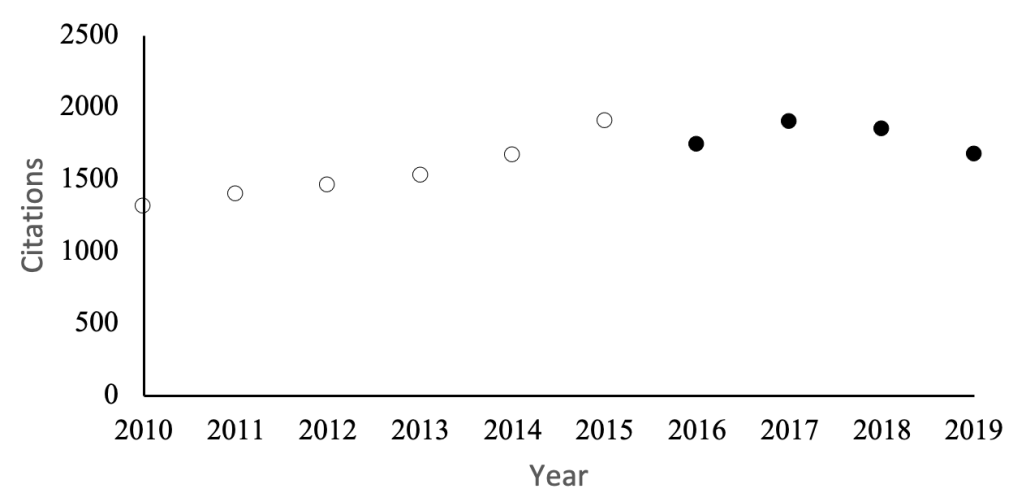

Next, figure 8 presents a scatterplot of the Google Scholar citation counts found for Friedrich Hayek. As with Mises's scholarship, although the mean of citations for the post-2015 period is slightly larger than for pre-2016, the series lacks an upward trend during the more recent period. More specifically, the latter portion of the series is quite clearly trending downward. ${ }^{34}$ As such, the series shown in figure 8 does not support a supply-side hypothesis.

${ }^{33}$ A linear trend line for the post-2015 period indicates that Google Scholar citations fell by 24.4 citations per year over this period.

${ }^{34}$ A linear trend line for the post-2015 period indicates that Google Scholar citations fell by 205.3 citations per year over this period. 
Figure 8. Google Scholar citations: Friedrich Hayek

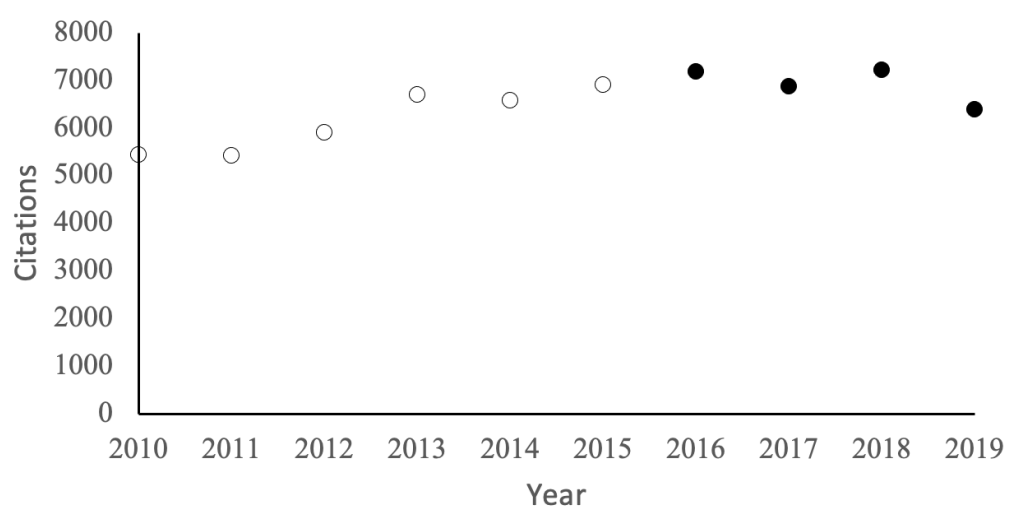

\section{Additional Discussion}

To summarize, the trend comparisons in the previous section of this study are generally consistent with the idea that the recent increase in support for socialism in US politics has been a boon to the Austrian school, and to Austrian economists Ludwig von Mises and Friedrich Hayek in particular. The argument supported by the empirical analysis above-that the rise of socialism in US politics has led to an increase in the demand for Austrian economics-has intuitive appeal. The Austrians, by virtue of constituting less than 5 percent of all academic economists (Vedder and Gallaway 2000), tend to rely more heavily on nontechnical expositions aimed at the wider public in order to garner greater interest. Additionally, many Austrians have involved themselves in politics directly (e.g., former US representative Ron Paul) or indirectly (such as through the Mises Institute).

The type of analysis presented above regarding the rise in interest in the ideas of the Austrian school that is owed to recent increases in support for socialism in US politics has wider application. For example, the 2019 impeachment of US president Donald Trump prompted renewed interest by Americans in the writings of America's founding fathers-contained in The Federalist Papers-on subjects such as the limits of the executive branch's power and the 
downside of hyperpartisan political processes. ${ }^{35}$ Similarly, recent growth in the economic power of US tech giants (e.g., Facebook, Amazon) combined with increasing income inequality has renewed Americans' interest in the Gilded Age (1870-early 1900s) and President Theodore Roosevelt's efforts to address these issues (Bruno 2019). ${ }^{36}$ There are certainly many other examples.

\section{LIMITATIONS AND POSSIBLE EXTENSIONS}

As with most examples of informetrics research, this study is not without its limitations. First, the use of data provided by large technology companies such as Google is subject to the many product (algorithm) changes that they make over time. For example, Lioudus (2019) reports on a significant change by Google in 2018 that "leveled the playing field for smaller publishers" by directing searches to small and medium-sized news publishers. The company again revised its algorithm in 2019 to favor original reporting over follow-up stories (Nieto and Arroyo 2019). To the extent that small and medium-sized news outlets have a proclivity for addressing stories related to Austrian economics and/or economists, the findings in this study are affected by algorithm changes to Google News such as those discussed in Lioudus (2019) and Nieto and Arroyo (2019). In addition to these concerns, there is also the overarching issue of the Google algorithm's use of a set of ranking factors to deliver relevant content, where relevance is determined in part by how well publishers optimize their content and by a particular user's preferences. ${ }^{37}$ All of these issues potentially impact the results of academic inquiry, including those presented in this study.

\footnotetext{
${ }^{35}$ Interestingly, during the Senate impeachment trial in early 2020, the president's defense counsel cited historical evidence of US president Abraham Lincoln's use of his authority as commander in chief to support his reelection efforts in the 1864 presidential election. Lincoln's activities in this regard are the subject of public choice studies by Anderson and Tollison (1991) and Crisp and Mixon (2011).

${ }^{36}$ Roosevelt's response ushered in the Progressive Era in the US (Bruno 2019). Thus, that episode is related to the subject of this study.

${ }^{37}$ Google News personalizes results on the basis of location, language, interests, and past activity, among others.
} 
The use of data from another large technology company, Twitter, also presents some issues that may relate to the study's findings. Twitter currently boasts 353 million users, up from only 54 million in 2010. This span approximates the time frame covered in this study. It is plausible that as Twitter became a social phenomenon over the 2010 to 2019 time period, independent-minded individuals holding favorable views of Austrian economics and/or economists adopted the channel in order to share their voices. It could also be the case that the activities of the Mises Institute, the Federal Reserve, and/or Gary Johnson's campaign for the US presidency generated substantial Twitter attention around Austrian economics and economists. Again, these issues potentially impacted the results presented above in this study. To work around some of the issues above, researchers commonly use Google Trends indices on search queries to gauge demand (e.g., see Silverstovs and Wochner 2018). A check of our results using a variety of Google Trends filters yielded less support for our hypothesis than reported in our analyses above. However, Google Trends too is subject to spurious patterns and other issues discussed above with regard to Google News (Bokelmann and Lessmann, 2019).

Future research might address some of the issues discussed above by applying "science mapping," or citation context analysis, described by Anderson and Lemkin (2020). As Gupta and Chaudhary (2021) explain, this approach assists researchers in describing how important ideas spread from source literature to subsequent research citing it. ${ }^{38}$ Gupta and Chaudhary (2021) apply the approach to the influence of Jacobson's (1992) seminal work on the field of organizational research..$^{39}$ Science mapping may prove useful in quantifiably addressing the quality of both the Google News results and Google Scholar citation counts that are analyzed in this and other similar informetric studies. Alternatives to the approach used by Gupta and Chaudhary (2021) for future research include use of the Bokelmann and Lessmann (2019) method for sanitizing Google Trends data to reduce the adverse

\footnotetext{
${ }^{38}$ See also Golden-Biddle, Locke, and Reay (2006).

${ }^{39}$ As Gupta and Chaudhary (2021) explain, Jacobson (1992) asserts that a firm's competitive advantage emanates from its ability to discover entrepreneurial opportunities, mobilize dispersed information, and innovate.
} 
impact of spurious patterns. Finally, perhaps a modified version of the hierarchical cluster analysis used in a recent study by Hwang et al. (2019) to classify productive management education scholars would prove helpful in further parsing the type of information provided by Google Scholar.

\section{CONCLUSION}

This study explored the possibility that the recent ascendance in the favorability of socialism in US politics has been a boon to the Austrian school of economics due to its thorough refutations of this ideology during the first half of the twentieth century. More specifically, two economists belonging to this school, Ludwig von Mises and Friedrich Hayek, devoted much of their professional careers to the study of socialism as a political economic ideology, and their scholarship on socialism represents what is arguably the most renowned rebuke of claims of socialism's superiority as a method of political and economic organization. As such, this study asserted that the Austrian school in general, and Mises and Hayek in particular, have been beneficiaries of the recent growth in the favorability of socialism in US politics. Put differently, the rise of socialism in US politics has led to an increase in the demand for Austrian economics.

Statistical tests of various informetrics trends support our assertion, as Google News hits and Twitter hashtag usage involving the views of prominent Austrian economists have generally ascended over the recent period (2016-19). The more recent era corresponds to the period of increased support for socialism in US politics as expressed through the increasing political fortunes of Democratic presidential candidate Bernie Sanders, Alexandria Ocasio-Cortez, and other prominent US legislators whose political platforms extol the virtues of socialist approaches to public policy. Lastly, the type of analysis presented in this study shows promise for wider application. For example, recent events surrounding the impeachment of the US president has renewed Americans' interest in the founders' views, as laid out in The Federalist Papers, on executive branch authority in the federal government, a subject of interest in both constitutional law and political science. Perhaps the events surrounding the impeachment has sparked increased 
interest in the constitutional philosophies of Alexander Hamilton and James Madison that might be evident across social media.

\section{REFERENCES}

Anderson, Marc H., and Russell K. Lemken. 2020. "Citation Context Analysis as a Method for Conducting Rigorous and Impactful Literature Reviews." Organizational Research Methods.

Anderson, Gary M., and Robert D. Tollison. 1991. "Political influence on Civil War Mortality Rates: The Electoral College as a Battlefield." Defence Economics 2, no. 3: 219-34.

Boettke, Peter J. 1990. The Political Economy of Soviet Socialism. Boston: Kluwer Academic Publishers.

— - 1994. The Collapse of Development Planning. New York: New York University Press.

- 2000. Calculation and Coordination. London: Routledge.

Boettke, Peter, and Christopher Coyne. 2004. "The Forgotten Contribution: Murray Rothbard on Socialism in Theory and Practice." Quarterly Journal of Austrian Economics 7, no. 2: 71-89.

Bokelmann, Björn, and Stefan Lessmann. 2019. "Spurious Patterns in Google Trends Data - an Analysis of the Effects on Tourism Demand Forecasting in Germany." Tourism Management 75, no. 1: 1-12.

Brazile, Donna. 2017. Hacks: The Inside Story of the Break-Ins and Breakdowns that Put Donald Trump in the White House. New York: Hachette Books.

Bruno,James.2019.“"TheLessonsofTheodoreRoosevelt.” WashingtonMonthly, Sept. 6, 2019. https://washingtonmonthly.com/2019/09/06/the-lessonsof-theodore-roosevelt/.

Caygle, Heather, Sarah Ferris, and John Bresnahan. 2019. "Pelosi and Ocasio-Cortez Clash Drags on, Threatening Democratic Unity." Politico, July 11, 2019. https://www.politico.com/story/2019/07/11/ nancy-pelosi-alexandria-ocasio-cortez-feud-1407292.

Cohen, Jacob. 1977. Statistical Power Analysis for the Behavioral Sciences. London: Routledge. 
Crisp, Alice M., and Franklin G. Mixon Jr. 2011. “Lincoln's Wartime Incumbency Network: Vertical Trust, Informal Payments, and the U.S. Presidential Election of 1864." Journal of Public Finance and Public Choice 29, nos. 1-3: 123-40.

Detrow, Scott, and Jessica Taylor. 2019. "Bernie Sanders Launches 2020 Presidential Campaign, No Longer an Underdog." NPR, Feb. 19, 2019. https://www.npr.org/2019/02/19/676923000/bernie-sanders-enters2020-presidential-campaign-no-longer-an-underdog.

Dickinson, H. D. 1939. Economics of Socialism. Oxford: Oxford University Press.

Dobb, Maurice. 1937. Political Economy and Capitalism. London: George Routledge.

Durlak, Joseph A. 2009. "How to Select, Calculate, and Interpret Effect Sizes." Journal of Pediatric Psychology 34, no. 9: 917-28.

Ekelund, Robert B., Jr., and Robert F. Hébert. 2014. A History of Economic Theory and Method. Long Grove, Ill.: Waveland Press.

Ellis, Paul D. 2010. The Essential Guide to Effect Sizes: Statistical Power, Meta-analysis, and the Interpretation of Research Results. Cambridge: Cambridge University Press.

Flannery, Nathaniel Parish. 2018. “Venezuela's Economic Crisis Keeps Getting Worse." Forbes, Mar. 22, 2018. https://www.forbes.com/ sites/nathanielparishflannery/2018/03/22/venezuelas-economiccrisis-worsens-in-2018/?sh=5c8d80201f17.

Freund, John E., and Frank J. Williams. 1972. Elementary Business Statistics: The Modern Approach. Inglewood Cliffs, N.J.: Prentice-Hall.

Gathright, Jenny, and Michel Martin. 2019 “Alexandria Ocasio-Cortez Says Bernie Sanders' Heart Attack Was a 'Gut Check' Moment." NPR, Oct. 19, 2019. https://www.upr.org/post/alexandria-ocasio-cortez-says-bernie-sanders-heart-attack-was-gut-check-moment.

Golden-Biddle, Karen, Karen Locke, and Trish Reay. 2006. “Using Knowledge in Management Studies: An Investigation of How We Cite Prior Work." Journal of Management Inquiry 15, no. 3: 237-54.

Graham, Luke. 2017. "Venezuela's Crisis Causes Its People to Cut Meals and Lose Weight." CNBC, Feb. 20, 2017. https://www.cnbc. com/2017/02/20/venezuelas-crisis-cause-its-people-to-cut-meals-andlose-weight.html. 
Grigoryan, Nune, and Wolfgang Suetzl. 2019. Hybridized political participation. In Alternative Media Meets Mainstream Politics: Activist Nation Rising, edited by Joshua D. Atkinson and Linda Kenix, 181-98. New York: Lexington Books.

Gupta, Vishal, and Sanjay Chaudhary. 2021. "Austrian Ideas in Management Scholarship: A Systematic Investigation of the Influence of Jacobson (1992) on Subsequent Research." Paper presented at the Austrian Economics Research Conference, Mises Institute, Auburn, Ala.

Harzing, Anne-Wil. 2016. "Publish or Perish." Harzing.com, Feb. 6, 2016. Updated Nov. 12, 2020. www.harzing.com/pop.htm.

Hayek, F. A. 1935. Collectivist Economic Planning. London: Routledge and Kegan Paul.

_ 1945. "The Use of Knowledge in Society." American Economic Review 35, no. 4: 519-30.

- 1948. Individualism and Economic Order. Chicago: University of Chicago Press.

Hedges, Larry V. 1981. "Distribution Theory for Glass's Estimator of Effect size and Related Estimators." Journal of Educational Statistics 6, no. 2: 107-28.

Hedges, Larry V., and Ingram Olkin. 1985. Statistical Methods for Metaanalysis. San Diego: Academic Press.

Heilbroner, Robert L. 1989. "The Triumph of Capitalism." New Yorker, Jan. 23, 1989.

_ . (1992) "An Economy in Deep Trouble: Proposals for Improvement." Dissent 39, no. 4: 445-50.

Holcombe, Randall G. 2014. Advanced Introduction to the Austrian School of Economics. Cheltenham, U.K.: Edward Elgar.

Hülsmann, Jörg Guido. 2007. Mises: The Last Knight of Liberalism. Auburn, Ala.: Ludwig von Mises Institute.

Hwang, Alvin, Regina F. Bento, J. B. Arbaugh, Carlos J, Asarta, Justin Cochran, Charles J. Fornaciari, and Christopher Jones. 2019. "A Cluster Analysis of Highly Productive Business and Management Education Scholars." Journal of Education for Business 94, no. 1: 21-30. 
Ikeda, Sanford. 1997. Dynamics of the Mixed Economy: Toward a Theory of Interventionism. London: Routledge.

Jacobson, Robert. 1992. "The 'Austrian' School of Strategy." Academy of Management Review 17, no. 4: 782-807.

Jones, Jeffrey M., and Lydia Saad. 2019. “U.S. Support for More Government Inches up, but Not for Socialism." Gallup, Nov. 18, 2019. https://news. gallup.com/poll/268295/support-government-inches-not-socialism.aspx.

Krieg, Gregory, and Annie Grayer. 2019. Rashida Tlaib Joins Ocasio-Cortez, Omar in Endorsing Bernie Sanders. CNN, Oct. 27, 2019. https://www. cnn.com/2019/10/27/politics/rashida-tlaib-endorses-bernie-sanders-aoc-omar/index.html.

Lange, Oskar R., and Fred M. Taylor. 1938. On the Economic Theory of Socialism. Minneapolis: University of Minnesota Press.

Lavoie, Don. (1985) 2015. Rivalry and Central Planning: The Socialist Calculation Debate Reconsidered. Reprint, Arlington, Va.: Mercatus Center.

Lerner, Abba Ptachya. 1946. The Economics of Control: Principles of Welfare Economics. New York: Macmillan.

Lioudis, Nick. 2019. "The New Google News: How Recent Changes Affect Referral Traffic Data." Chartbeat. Accessed July 8, 2021. https://blog. chartbeat.com/2019/10/03/google-news-referral-traffic-data/.

Lipsey, Mark W., and David B. Wilson. 2000. Practical Meta-analysis. New York: SAGE Publications.

Lovelace, Berkeley, Jr. 2019. "Alexandria Ocasio-Cortez Says She Plans to Oppose House Speaker Nancy Pelosi's Drug Pricing Bill. CNBC, Dec. 10, 2019. https:/www.cnbc.com/2019/12/10/alexandria-ocasio-cortezsays-she-plans-to-oppose-pelosis-drug-bill.html.

Manish, G. P. 2011. “Central Economic Planning and India's Economic Performance, 1951-65." Independent Review 16, no. 2: 199-219.

- 2013. "Market Reforms in India and the Quality of Economic Growth." Independent Review 18, no. 2: 241-62.

— . 2014. "Qualitative Aspects of the Indian Growth Spurt of the 1980s." Review of Austrian Economics 27, no. 3: 325-40. 
Merica, Dan. 2015. “Bernie Sanders Is Running for President." CNN, Apr. 30, 2015.

Mermin, Gordon, Len Burman, and Frank Sammartino. 2015. An Analysis of Senator Bernie Sanders's Tax and Transfer Proposals. Washington, D.C.: Tax Policy Center.

Mises, Ludwig von. 1990. Economic Calculation in the Socialist Commonwealth. Translated by S. Adler. Auburn, AL: Mises Institute.

_ 1962. Socialism: An Economic and Sociological Analysis. Translated by J. Kahane. New Haven, Conn.: Yale University Press.

Nieto, Carmen Arroyo, and Josep Valor. 2019. “Google News Changes Its Algorithm, and withIt, theMediaIndustry." MediaMattersBlogNetwork, Oct. 28, 2019. https://blog.iese.edu/the-media-industry/2019/10/28/ google-news-changes-its-algorithm-and-with-it-the-media-industry/.

Reisman, George. 1998. Capitalism: A Treatise on Economics. Ottawa, Ill.: Jameson Books.

Rothbard, Murray N. (1962) Man, Economy, and State. Auburn, AL: Reprinted by the Ludwig von Mises Institute.

Rothbard, Murray N. $(1962,1970)$ 2009. Man, Economy, and State, with Power and Market. 2d scholar's ed. Auburn, Ala.: Ludwig von Mises Institute.

Salerno, Joseph T. 1990. "Why a Socialist Economy Is 'Impossible."' Postscript to Economic Calculation in the Socialist Commonwealth. Auburn, Ala.: Ludwig von Mises Institute.

Sanchez, Valentina. 2019. "Venezuelan Hyperinflation Hits 10 Million Percent. 'Shock Therapy' May Be Only Chance to Undo the Economic Damage. CNBC, Aug. 3, 2019. Updated Aug. 5, 2019. https://www. cnbc.com/2019/08/02/venezuela-inflation-at-10-million-percent-itstime-for-shock-therapy.html.

Sequera, Vivian. 2018. "Venezuelans Report Big Weight Losses in 2017 as Hunger Hits." Reuters, Feb. 21, 2018. https://www.reuters.com/article/ us-venezuela-food-idUSKCN1G52HA.

Shenoy, B. R. 1958. Problems of Indian Economic Development. Madras, India: University of Madras.

—. 1963. Indian Planning and Economic Development. Mumbai: Asia Publishing House. 
— 1966. Fifteen Years of Indian Planning. Mumbai: Forum of Free Enterprise.

— 1971. India: Progress or Poverty? London.: Institute of Economic Affairs.

Silverstovs, Boriss, and Daniel S. Wochner. 2018. "Google Trends and Reality: Do the Proportions Match? Appraising the Informational Value of Online Search Behavior: Evidence from Swiss Tourism Regions." Journal of Economic Behavior and Organization 145, no. 1: 1-23.

Vedder, Richard, and Lowell Gallaway. 2000. "The Austrian Market Share in the Marketplace for Ideas, 1871-2025." Quarterly Journal of Austrian Economics 3, no. 1: 33-42. 